\title{
Customers' Perspective towards Customer Relationship Management with reference to Service Quality: A Study of Indian Public and Private Sector Banks
}

\author{
Manjari Mishra ${ }^{1}$ \\ ${ }^{I}$ (Professor, RIMT-IMCT, Mandi Gobindgarh, India)
}

\begin{abstract}
The paper studies the bank customers' perspective regarding customer relationship management (CRM) practices with refence to service quality of the Public and Private sectors banks in India. In todays scenario, when markets have become highly competitive due to globalization and privatization, customer relationship management (CRM) is gaining importance for successful growth of the banking industry. The study holds importance as marketeers have to find ways to increase the number of new customers alongside the rention of old ones. In order to conduct the study stratified random sampling was adopted and a sample of 240 bank customers was interviewed. It was indicated in the study that the perspective of customers regarding CRM and service quality has significant difference in terms of the bank category, i.e. public and private Indian banks.Further, when results were compared on the basis of gender, the results reflected a difference in perspective of Customer Relationship Management (CRM) and service quality among customers of private sector banks but this was not so in case of public sector banks. The research gave insights not only for the benefits of Indian banks, but also paved a way for further research in the area of academics. It clearly indicate the importance of development of strong CRM and service quality measures so as to fulfill the requirement of both male and female customers. The study also aid banks in deciding the customer oriented strategies in order to create differentiation for the banks.
\end{abstract}

Keywords- bank customers, customer relationship management, private banking, public sector banks,.

\section{INTRODUCTION}

Customer expectations have overgrown many a times due to tough competition in the industry and hence the best possble way to differentiate itself is to offer improving service quality and adopt CRM strategies with special refence on service quality.

Customer Relationship Management (CRM) has been considered a philosophy which proves to be highly beneficial in building long term relationships with customers. Buttle, 2000, defined CRM as "the development and maintenance of mutually beneficial long-term relationships with strategically significant customers" (Buttle, 2000). The benefits accrued by implementing CRM has gained high importance as retaining customers is three times cheaper than finding a new one and CRM strategies are regarded as best possible measure for an organisation in achieving high retention of customers and hence higher earnings. CRM strategy lay emphasis on acquiring and retaining customers so that there is enhancement in the profitability of the organization as well as the customers, which can be achieved by implementing service quality measures.

In last decade banking as a industry has seen drastic changes in the way customers have expected better service quality and they have also started adopting technologies innovations. Businesses have responded to these changes and have come in a big way in marked to pose strong competition to other businesses (Gardender et al., 1999). The idea of building relationship with the customer and making it profitable is quite old as earlier businesses also made profitable relationships with customers and tried to make them regular customers (Jobber, 2004). For businesses in service, maintaining customer relationships is crucial because services are focused on interpersonal relationships (Czepiel, 1990). Banks, thus, have started focusing on service quality and use it as a tool to retain existing customers. Service quality is a way to evaluate reliability, assurance, responsiveness, empathy and tangibles of services from the perspective of customers (Parasuraman 
et al., 1988). Zeithaml and Bitner (1996) laid emphasis on strengthening of customer relationship which becomes an automated thing once customers starts thinking positively about the services offered by the organization. Research also indicates that service quality is related to the cost that is borne by the company and the customers (Crosby, 1979), Satisfaction of Customer (Bolton and drew, 1991 and Boulding et al 1993), Profits earned by the organization (Buzzell and Gale, 1987, and Rust and Zahorik 1993) and the number of customers retained (Reichheld and Sasser 1990).

Since, the policy of LPG, many baks heve flooded the Indian market and all, to survive and grow are trying to find ways and means to keep their customers satisfied. Though, lot of work is done on CRM, but not much research is taken up which provides insight on future prospects of gains of an organization and also of the customers. The research has been conducted to understand the relation between customer relationship management wrt service quality and customer perspective

The research has also worked towards the understanding how customer perspective is affected by customer satisfaction and in what manner it is related to commitment and loyalty of a customer, which signifies the importance of CRM adoption in Indian banks.

\section{REVIEW OF LITERATURE}

In the study by Peppers et al. (1999), steps in CRM implementation were proposed and observed its impact on customer service. Paper considered it desirable to implement CRM by organizations as CRM strategies results into numerous benefits like greater loyalty and higher profits. Banks, with time have realized that good service quality is essential for the growth and survival of businesses due to a very strong competition in the business environment (Wang et al., 2003). The benefits which are offered by an organization to the consumer can be defined as the service. These are the facilities provided to satisfy a particular need or want of the customer. Banks are also service provider agencies which offer not just the financial consultancy but other financial services also. This indicates a complete diversification of services over a period of time. It is clear that intangibility, perishability, inseparability and heterogeneity of services make it different from the products (Parasuraman et al., 1985; Hoffman and Bateson, 2002) and service quality is considered to be an important factor in acquiring a new customer and retaining an existing one (Galloway and Ho, 1996). Service quality is one way to differentiate the offerings of an organization in order to enhance its competitive position for the long term benefits in terms of profitability and marketability (Morre, 1987). Another research emphasized that organizations need to offer better services in accordance to the requirements of the customers (Hanson, 2000). Another research clearly indicated that service quality and customer satisfaction are linked to each other as it helps in deciding what customers need and what is being delivered by the organization to fulfill customers' requirement (Spreng and Machoy, 1996; Woodside et al., 1989). Another definition given for service quality is by Hartline and Ferrell, 1996; Zeithaml and Parasuraman, 2004, wherein they explained that the difference between what customers expect and what is being perceived by them is service quality, and this can be achieved by implementing CRM.

\section{RESEARCH METHODOLOGY}

The study has been conducted on the customers of public and private sector banks operating in urban punjab. To choose the sample for the research top four banks in terms of number of branches of each public and private sector are taken. A sample of 600 respondents, 75 from each bank are picked. The data is selected with the help of using stratified random sampling. From each group of bank, i.e public and private sector banks customers were selected randomly to study their responses. Responses of customers of public and private sector banks were recorded using a self administered structured questionnaire as an instrument. List of banks opted for this study is listed in Table 1. To record the response respondents of Patiala, Ludhiana and Chandigarh were interviewed. Customers were asked to give their responses regarding their banks' customer relationship management practices keeping in view various aspects of service quality. The questionnaire was designed on 
the basis of SERVQUAL model given by Parasuraman et al. (1988). There are 22 items in the questionnaire on the basis of above model which covers various dimensions of service quality. All the five aspects of service quality i.e. tangibility, reliability, responsiveness, assurance and empathy are assessed using a seven point Likert scale where the numbers 1-7 denote the following: $1=$ strongly disagree to $7=$ strongly agree. The variables are also checked for internal consistency and reliability and it is tabulated in Table 2.

\section{DATA ANALYSIS}

Demographics of the sample chosen is studied by using descriptive statistics and t- test is adopted to study whether there is any difference in the perspective of bank customers about CRM wrt service quality in cities under study or not. Alongside, standard deviation is used to measure perspective of bank customer. Study of demographics reflects that the number of male customers is more than that of female respondents. In case of private sector banks $79 \%$ are male respondents and $21 \%$ are females. While in case of public sector banks, male respondents are $77 \%$ and female respondents are just $23 \%$. This shows that male respondents are more inclined toward choosing private sector banks in comparison to female customers who preferred public sector banks. When respondents was studied on the basis of age, it was found that respondents in the age group of $25-40$ preferred private banks while respondents in the age group of $18-25$ years choose more of public banks. Table 3 shows the analysis of customers' perspective towards CRM wrt to service quality of private and public sector banks. It has been analysed that private banks are better in implementing CRM and service quality measures as compared to public sector banks. Also, the similar results are being reflected while studying customer's perspective regarding CRM wrt service quality. As reflected by the scores (mean and sum) customers hold better perspective towards private banks than public sector banks as there is lesser dispersion. Table 4 shows the result of analysis of customers' perspective towards CRM and service quality aspects of private banks. The value, 1.505 of Levene's statistic for equality of variances has not come out to be significant i.e. $p=0.223$. The results for $\mathrm{t}$-test has come out to be 3.649 which is highly significant as value of $\mathrm{p}$ is 0.000 . this result confirms that perspective of male and female customers about service quality of Private Sector is significantly different.

TABLE I. Banks Taken for the Study

\begin{tabular}{|l|l|l|}
\hline S.No. & Public Sector Banks & Private Sector Banks \\
\hline 1 & State Bank of India & HDFC Bank \\
\hline 2 & State Bank of Patiala & ICICI Bank \\
\hline 3 & Oriental Bank of Commerce & Axis Bank \\
\hline 4 & Punjab National Bank & Kotak Mahindra Bank \\
\hline
\end{tabular}

TABLE II. Reliability Statistics of the Scales for the Private Sector Banks

\begin{tabular}{|c|c|c|c|c|c|}
\hline \multirow[t]{2}{*}{$\begin{array}{l}\text { Variables for the } \\
\text { Research }\end{array}$} & \multirow[t]{2}{*}{$\begin{array}{l}\text { No. of } \\
\text { Items }\end{array}$} & \multicolumn{2}{|c|}{ Cronbach's Alpha } & \multicolumn{2}{|c|}{ Guttman Split-Half } \\
\hline & & $\begin{array}{l}\text { Private } \\
\text { Sector Banks }\end{array}$ & $\begin{array}{l}\text { Public } \\
\text { Sector } \\
\text { Banks }\end{array}$ & $\begin{array}{l}\text { Private } \\
\text { Sector Banks }\end{array}$ & $\begin{array}{l}\text { Public Sector } \\
\text { Banks }\end{array}$ \\
\hline Service Quality & 22 & 0.909 & 0.897 & 0.952 & 0.896 \\
\hline
\end{tabular}


IOSR Journal of Business and Management (IOSR-JBM)

e-ISSN: 2278-487X, p-ISSN: 2319-7668

\begin{tabular}{|l|l|l|l|l|l|} 
Tangibility & 4 & 0.831 & 0.812 & 0.845 & 0.831 \\
\hline Reliability & 5 & 0.820 & 0.876 & 0.764 & 0.775 \\
\hline Responsiveness & 4 & 0.717 & 0.765 & 0.784 & 0.759 \\
\hline Assurance & 4 & 0.789 & 0.785 & 0.755 & 0.758 \\
\hline Empathy & 5 & 0.885 & 0.871 & 0.877 & 0.838 \\
\hline
\end{tabular}

TABLE III. Comparison of CRM wrt service quality dimensions of Public Sector Banks and Private Sector Banks.

\begin{tabular}{|l|l|l|l|l|l|}
\hline & Minimum & Maximum & Sum & Mean & Deviation \\
\hline Pvt. Banks Tangible & 1.50 & 7.00 & 1893.50 & 5.2597 & 1.14142 \\
\hline Pvt. Banks Reliability & 1.40 & 7.00 & 1850.60 & 5.1406 & 0.99487 \\
\hline Pvt. Banks Responsiveness & 1.75 & 7.00 & 1861.75 & 5.1715 & 1.03150 \\
\hline Pvt. Banks Assurance & 1.75 & 7.00 & 1915.00 & 5.3194 & 0.94543 \\
\hline Pvt. Banks Empathy & 1.80 & 7.00 & 1857.00 & 5.1583 & 1.04671 \\
\hline Pvt. Banks Service Quality & 2.42 & 6.72 & 1875.57 & 5.2099 & 0.89718 \\
\hline Pub. Sec. Banks Tangible & 1.25 & 7.00 & 1794.75 & 4.9854 & 1.19261 \\
\hline Pub. Sec. Banks Reliability & 1.20 & 7.00 & 1798.80 & 4.9967 & 1.04163 \\
\hline Pub. Sec. Banks Responsiveness & 1.25 & 7.00 & 1762.50 & 4.89958 & 1.09915 \\
\hline Pub. Sec. Banks Assurance & 1.50 & 7.00 & 1816.75 & 5.0465 & 1.02854 \\
\hline Pub. Sec. Banks Empathy & 1.00 & 6.80 & 1752.40 & 4.8678 & 1.07505 \\
\hline Pub. Sec. Banks Service Quality & 1.65 & 6.54 & 1785.04 & 4.9584 & 0.93404 \\
\hline
\end{tabular}


TABLE IV. Results of t-test to study difference in the customers' perspective on the basis of gender of Private Banks regarding service quality

\begin{tabular}{|l|l|l|l|l|l|l|l|l|l|}
\hline Gender & N & M & Std. Dev. & \multicolumn{2}{|l|}{$\begin{array}{l}\text { Values for } \\
\text { Levene's Test }\end{array}$} & \multicolumn{2}{|l|}{ T-test for Eqality of Mean } \\
\hline & & & & F & Sig & t & df & Sig (2 tailed) \\
\hline Female & 126 & 5.29 & 0.86 & & & & & \\
\hline Male & 474 & 4.88 & 0.95 & 1.505 & 0.223 & 3.649 & 348 & 0.000 \\
\hline
\end{tabular}

TABLE V. Results of t-test to study difference in the customers' perspective on the basis of gender of Public Sector Bank regarding service quality

\begin{tabular}{|l|l|l|l|l|l|l|l|l|}
\hline Gender & N & M & Std. Dev. & \multicolumn{2}{|l|}{ Values for } \\
Levene's Test
\end{tabular}

Results Customers' perspective of CRM and service quality of public sector banks after using t-test are reflected in Table 5.In this case also the value of Levene's statistic is 0.007 for equality of variance which is not significant as value for $\mathrm{p}$ is 0.942 .0 .009 is the value for t-test for equality of the mean is and is insignificant as value for $\mathrm{p}$ is 0.989 . This means that in case of public sector banks customers' perspective on the basis of gender is not significant. Results also indicate that the perspective of male customers of private banks is significantly different from the perspective of female customers. Whereas, when looked into the perspective of male and female customers of public sector banks, no difference has been identified regarding the service quality of public sector banks. The results further emphasize that the there are more male customers using bank services in comparison to female customers. Similarly, customers of private banks generally are of the age group of $25-40$ yearswhereas in case of public sector banks the age group of customers is $18-25$. Results reveal that the customer perspective regarding CRM wrt service quality is different among customers of private and public sector banks. Results indicate that perspective of male customers towards CRM wrt service quality is highly different from the perspective of female customers in case of private banks. It is also realized that customer's demographics is significant in developing a perspective towards banking. Whereas, male and female customers perspective about the CRM and service quality is not different in case of public sector banks.

\section{SUMmary AND CONCLUSION}

This study reveals that the private banks are more focused in implementing service quality aspect of customer relationship management as compared to public sector banks. This is offering a chance of growth to private banks and they are giving strong competition to public sector banks. It can further be summed up that customers of private banks have more positive perspective regarding CRM and service quality when compared to the customers of public sector banks. Also, there is difference in pespective on te basis of gender in case of 
private baks but this is not the case with public banks. The study reflects that banks must consider demographic characteristics of the customers to decide about better quality initiatives to improve their services. Banks must also find an effective strategy to woo more of female customers, this can be done by customizing services to meet their specific needs. This research is useful for private banks because they invest heftly to attract larger customers to increase profitability but these efforts cannot pay the required benefits unless their is strong CRM strategy.

\section{REFERENCES}

[1] N.B. Ruth and H.D. James, "A Longitudinal Analysis of the impact of service changes on customer attitudes", Journal of Marketing, 55(1), 1991, 1-10.

[2] W. Boulding, A. Karla, R. Staelin and V.A. Zeithaml, "A dynamic process model of service quality: From expectations to behavioural intentions", Journal of Marketing Research, 30(1), 1993, 7-27.

[3] F. Buttle, The S.C.O.P.E. of Customer Relationship Management, 2002.

[4] R.T. Buzzell and B.T. Gale, The PIMS Principles, (Free Press: New York, 1987).

[5] P.B. Crosby, Quality is free - The Art of Making Quality Certain, (Mc Graw Hill: New York, 1979).

[6] J. A. Czepiel, "Service Encounters and Service Relationships: Implication for Research", Journal of Business Research, 20 (1), 1990, 13-21.

[7] L. Galloway and S Ho, "The model of service quality for training, Training for Quality", 4(1), 1996, 20-26.

[8] E. Gradener, J. Howcroft and J. Williams, "The New Retail Banking Revolution”, The service industries Journal, 19(2), 1999, 83-100.

[9] W. Hanson, Principles of Internet Marketing, (Cincinnati, Ohio: South-Western, 2000).

[10] M. Hartline and O. Ferrell, "The Management of customer - contact service employees: An Empirical Investigation", The Journal of Marketing, 60(4), 1996, 52-70.

[11] K.D. Hoffman, J.E. Bateson, Essentials of Services Marketing: Concepts, Strategies, and Cases, (2), (Harcourt College Publishers, 2002).

[12] D. Jobber, Principles of Marketing. Bershire, (England: McGraw-Hill International, 2004).

[13] C.D. Morre, Outclass the Competition with Service Distinction, Mortgage Bank, 1987, 11-47.

[14] A. Parasuraman, V.A. Zeithaml, L. Berry, "A conceptual model of service quality and its implications for future research", J. Mark, 49, 1985, 41-50.

[15] A. Parasuraman, V.A. Zeithaml and L.L.Berry, "SERVQUAL: A multiple item scale for measuring customer perception fo service quality”, Journal of Retailing, Spring, 64, 1988, 12-40.

[16] D. Peppers, M. Rogers and B. Dorf, "Is Your Company Ready For One-To-One Marketing?", Harvard Business Review, 77(1), 1999, 151-160.

[17] F. F. Reichheld and W. E. Sasser (Jr), "Zero Detections: Quality Comes to service”, Harvard Business Review, 68(5), 1990, 105-111.

[18] R T Rust and A J Zahokik, "Customer Satisfaction, Customer Retention and Market share”, Journal of Retailing, 69(2), 1993, 193215.

[19] R.A. Spreng and R.D. Mackoy, “An empirical examination of a model of perceived service quality and satisfaction”, J. Retailing, 72, 1996, 201-214.

[20] Y. Wang, H. Lo and YV Hui, "The antecedents of service quality and product quality and their influences on bank reputation: evidence from banking industry in China". Manag Serv. Qualit., 13(1), 2003, 72-83.

[21] AG Woodside, LI Fery and RT, "Daly Linking service quality, customer satisfaction, and behavioral intention", J. Health Care Mark, 9(4), 1989, 5-17.

[22] V.A. Zeithaml and M.J. Bitner, Service Marketing, (International Edition, McGrawhill: New York and London, 1996),

[23] V Zeithmal and A Parasuraman, Service Quality, MSI Relevant Knowledge Series, (Cambridge: MA, 2004). 